\title{
An Aspect of Feeding Behavior and Its Importance to Grazing Systems
}

\author{
ERNEST A. GLUESING AND DAVID F. BALPH
}

\begin{abstract}
A study of domestic sheep (Ovis aries) showed significant $(P<0.001)$ differences in the amount of time ewes walked while grazing in different pastures when the forage in the new pasture differed from that of the previous pasture. Ewes searched for alfalfa in a new pasture when it was a major constituent of the previous pasture, but did not appear to search for alfalfa in a new pasture if it was not a major constituent of the previous pasture. Ewes appeared to adjust to less preferred diets within a few days and modified their grazing behavior accordingly. The management implications of prior conditioning are discussed.
\end{abstract}

Some specialized grazing systems present livestock with a succession of pastures that differ in vegetation composition and growth stage: Animals in such systems often exhibit disappointing weight gains (reviewed by Heady 1961, 1975). Part of the problem may lie in the animal's responses to new or different plant communities. For example, if animals are placed in a new pasture that contains fewer preferred food plants than they are accustomed to, the animals may spend time and energy searching for the more preferred species. Prior experience with specific vegetation may even influence their diet (Arnold 1964, Arnold and Maller 1977). A more complete understanding of the behavioral consequences of shifting livestock from one vegetation type to another may provide some insight into designing better grazing systems. This paper examines the proportion of time sheep spend moving after being placed in pastures of differing vegetation composition.

\section{Methods}

The study was conducted on the Cook Ranch near Florence, Montana. Topography within the area varied from open and flat to rolling hills with wooded draws. Vegetation consisted primarily of wheat grasses (Agropyron cristatum, A. intermedium, A. spicatum), cheatgrass (Bromus tectorum), fescue (Festuca ovina), alfalfa (Medico sp., Onobrychis viciaefolia), sagebrush (Artemisia sp.), lupine (Lupinus sp.), spotted knapweed (Centaurea maculosa), ponderosa pine (Pinus ponderosa), and black cottonwood Populus trichocarpa). Pastures varied in size 21.5-325.4 ha; $\mathrm{N}=6$, $x=132.3, S . D .=108.8$ ) and in vegetative composition (Table 1 ). An index of vegetative composition in each pasture was obtained by recording the most abundant plant in a $1-\mathrm{m}^{2}$ quadrat every 100 steps in a succession of transects 100 steps apart.

The study herd originally consisted of 624 ewes and 954 lambs. Ewes ranged in age from 1-6 years; there were 340 Targhees, 137 Columbias, 128 black-white-face crosses, and 19 unclassified. Each ewe was individually identifiable at a distance. A random sample of 44 ewes (hereafter referred to as sample ewes) was marked with red

Authors are graduate assistant and professor, Department of Wildlife Science, Utah State University, Logan, 84322. E.A. Gluesing is at present assistant professor, Department of Animal Ecology, Iowa State University, Ames 50011

The authors thank Fred Knowlton, Predator Ecology and Behavior Unit, Utah State University, Logan for his assistance, and the U.S. Fish and Wildlife Service (Contract No. 14-16-0008-850) for financial support.

Manuscript received May 7, 1979. paint to facilitate locating them within the herd.

As part of a broader investigation (Gluesing 1977), the frequency of nine activities of the sample ewes was made daily between 0600 and 2100 hours during the summer of 1975. Each sample ewe was observed for a 15-minute period 38-43 times $(x=40.6$, S.D. $=$ 1.16). During each observation period the activity of the ewe was recorded every 20 seconds and her location in the pasture every 5 minutes during the observation period. The data relevant to this paper was the proportion of time sample ewes spent walking while grazing in six pastures.

\section{Results and Discussion}

Ewes walked a significantly $(P<0.001)$ different amount in the pastures (Table 1). However, the major difference (89\% contribution to Chi-square) was in their movement in two pastures.

The ewes first grazed in pasture no. 2, which contained $48 \%$ grasses, $37 \%$ alfalfa, and $15 \%$ other plant species. They ate mostly alfalfa and spent little time walking between plants. The grazing sheep reached the opposite end of the pasture (1.4 km away) on the third day.

The herd was in pasture no. 2 for 22 days and then was moved to pasture no. 3 , which contained $57 \%$ grasses, $29 \%$ alfalfa, and $14 \%$ other plant species. Again, the sheep ate mostly alfalfa and spent little time walking between plants. They reached the opposite end of pasture $(1.1 \mathrm{~km}$ away) on the second day.

When the sheep were moved to pasture no. 5, which contained $53 \%$ alfalfa, they walked about $40 \%$ less than expected (under the assumption of equal proportion of time spent walking in all pastures). The sharp decrease in proportion of time spent walking when the animals were placed in pasture no. 5 is consistent with what would be expected with some models of food exploitation (search image, Tinbergan 1960; functional response, Holling 1966; and discrimination training, Sutherland and Mackintosh 1971).

When the ewes were transferred from pasture no. 5 to pasture no. 6 , which contained less than $5 \%$ alfalfa, they walked about $50 \%$ more than expected. Their behavior suggested that they spent considerable time searching for alfalfa plants. This was particularly pronounced when the sheep were first released into the pasture; they walked the entire perimeter (approximately $4 \mathrm{~km}$ ) in less than $3 \mathrm{hrs}$.

The rancher enlarged pasture no. 6 after 7 days to include 155.4 ha of similar vegetation (pasture no. 7). Although the ewes grazed over the entire area, the amount of time ewes walked in pasture no. 7 was only 65 percent of what it was in pasture no. 6. The activity of the ewes suggested that by the time pasture no. 6 was enlarged to create pasture no. 7 , they were accustomed to the scarcity of alfalfa and no longer searched for the plant to the extent they had initially.

The observations presented may have some management 
Table 1. The amount of time ewes walked in different pastures as a proportion of all activities. Pasture no. 7 consisted of pasture no. 6 plus an adjoinin 155.4 ha. Pasture no. 9 was the combination of pastures no. 2 and no. 3. Ewes were placed in pastures no. 2 through no. 9 sequentially.

\begin{tabular}{|c|c|c|c|c|c|c|c|}
\hline \multirow{2}{*}{$\begin{array}{l}\text { Pasture } \\
\text { number }\end{array}$} & \multirow{2}{*}{$\begin{array}{l}\text { Days in } \\
\text { pasture }\end{array}$} & \multirow{2}{*}{$\begin{array}{l}\text { Times spent } \\
\text { walking }\end{array}$} & \multirow{2}{*}{$\begin{array}{l}\text { Contribution } \\
\text { to Chi-square }\end{array}$} & \multirow{2}{*}{$\begin{array}{l}\text { Pasture } \\
\text { size (ha) }\end{array}$} & \multicolumn{3}{|c|}{ Vegetation type (\% abundance) } \\
\hline & & & & & Alfalfa & Grasses & Other \\
\hline 2 & 22 & 0.1171 & 7.70 & 79.7 & 37 & 48 & 15 \\
\hline 3 & 16 & 0.1021 & 11.14 & 59.1 & 29 & 57 & 14 \\
\hline 5 & 11 & $0.0643^{\mathrm{al}}$ & 133.76 & 21.5 & 53 & 38 & 9 \\
\hline 6 & 7 & $0.1858^{\mathrm{b} 2}$ & 164.92 & 170.0 & 4 & 73 & 23 \\
\hline 7 & 11 & 0.1201 & 4.17 & 325.4 & 4 & 71 & 25 \\
\hline 2 & 15 & 0.1026 & 7.92 & 79.7 & 37 & 48 & 15 \\
\hline \multirow[t]{2}{*}{9} & 21 & 0.1208 & 7.75 & 138.8 & 34 & 52 & 14 \\
\hline & & & $337.36^{* 3}$ & & & & \\
\hline
\end{tabular}

1a Significantly lower than other pastures
${ }^{2 b}$ Significantly higher than other pastures

$3 * P<0.001$

implications. In those grazing systems that cause sheep to graze inefficiently by searching for a few preferred plants, the time and energy spent in the search might be reduced by confining the sheep to a small portion of the larger pasture. Presumably, they would become accustomed to the quality and quantity (per unit area) of the pasture vegetation in the smaller area, and thus, walk less, trample less vegetation, and feed proportionately more when allowed access to the entire pasture. In experiments in a 0.5 -ha enclosure simulating a mixture of food items and dispersion patterns, sheep adjusted to new feeding conditions in 2-3 days (Razmi 1978)

\section{Literature Cited}

Arnold, G.W. 1964. Some principles in the investigation of selective grazing. Proc. Aust. Soc. Anim. Prod. 5: 258-271.
Arnold, G.W., and R.A. Maller. 1977. Effects of nutritional experience i early and adult life on performance and dietary habits of sheep. App Anim. Ethol. 3: 5-26.

Gluesing, E.A. 1977. Sheep behavior and vulnerability to coyote predatior PhD Diss. Utah State University, Logan. 121 p.

Heady, H.F. 1961. Continuous vs. specialized grazing systems: a review an application to the California annual type. J. Range Manage. 17: 76-8.

Heady, H.F. 1975. Range Manage. McGraw Hill, New York. 460 p.

Holling, C.S. 1966. The functional response of invertebrate predators $t$ prey density. Mem. Entomol. Soc. Can. 48: 1-86.

Razmi, K. 1978. Feeding behavior of sheep with respect to food-relate cues in the environment. Ph D Diss. Utah State University, Logan. 12 p.

Sutherland, N.S. and N.J. Mackintosh. 1971. Mechanisms of Anim: Discrimination Learning. Academic Press, New York. 559 p.

Tinbergen, L. 1960. The natural control of insects in pine woods. 1. Factor influencing the intensity of predation by songbirds. Arch. Neerl. Zoo 13: 265-336. 